Ніна Володимирівна Теремцова, кандидат юридичних наук, дочент кафедри теорії права та держави юридичного факультету Київського начіонального університету імені Тараса Шевченка

\title{
ОСОБЛИВОСТІ ЮРИДИЧНОЇ ВІДПОВІДАЛЬНОСТІ СУБ'СКТІВ ПРИВАТНОГО ПРАВА
}

Постановка проблеми. Проблема юридичної відповідальності майже в повному обсязі висвітлена на сторінках як вітчизняної, так і зарубіжної юридичної літератури, що само по собі не виключає можливість дослідження окремих іiі аспектів в руслі теорії як приватного права, так і загальної теорії права. На сьогодні, навряд чи можна сказати, що за останні 10 років вітчизняна правова наука просунулася в розробці теоретичних проблем юридичної відповідальності, вирішивши дану проблему. Тому проблема юридичної відповідальності, незважаючи на те, що вона обговорюється протягом декількох десятків років, не втратила своєї актуальності. Крім питань, що стосуються видів відповідальності та поняття юридичної відповідальності, тут можна виділити більш обгрунтовані питання, що висвітлюють визначення підстав юридичної відповідальності, класифікації видів відповідальності, виділення нових видів відповідальності тощо.

Досягнення мети полягає в тому, щоб довести, що основними критеріями юридичної відповідальності суб'єктів приватного права є характерним задоволення позитивних благ у всьому суспільстві. Відповідно, до приватного права належать норми та принципи, що регулюють правовідносини між фізичними й юридичними особами, які задовольняють переважно індивідуальний інтерес.

Аналіз останніх досліджень та публікацій. Значний внесок щодо розробки цієї проблематики зробили науковці, С. С. Алексєєв, К. В. Басін, Л. В.Борисова, С. О. Іванова, В. В. Копєйчиков, В. О. Котюк, В. В. Лазарєв, М. М. Марченко, Н. М. Оніщенко, Н. В. Теремцова, Ю. С. Харитонова тощо.

На сьогодні залишається чисельна кількість питань щодо юридичної відповідальності, особливості окремих елементів щодо суб'єктів приватного права, як динамічної категорії в теорії права, а також значення юридичної відповідальності, що має важливе теоретичне та практичне значення, залишаються невирішеними й недостатньо вивченими в теорії права та юридичній науці.

Мета статті. Сучасні спроби переосмислити сутність юридичної відповідальності і сформулювати дещо нове, оригінальне визначення поняття юридичної відповідальності в даний час вказують на існування двох тенденцій. В одних випадках відповідальність повністю ототожнюється з санкцією, що застосовується до правопорушника [4], в інших під нею розуміється елемент структури правовідносини, що забезпечує неминучість виконання покладеного на особу зобов'язання, необхідність настання несприятливих наслідків за невиконання (неналежне виконання) суб'єктами права своїх обов'язків і за зловживання правом [7, с. 8] тощо. Крім того, в юридичній літературі, як і раніше, поширена точка зору, прихильники якої не намагаються дати загальне визначення терміну юридичної відповідальності, а розглядають їі як складне структурне утворення, що характеризується кількома ознаками або включає декілька компонентів.

Основні результати дослідження. Постановка проблеми. Актуальним напрямком у теоретико-правовій науці є дослідження проблеми щодо особливостей юридичної відповідальності суб'єктів приватного права. Сутність даного дослідження полягає в тому, що, крім галузей в структурі права, юридичні норми можна поділити на дві великі групи: на приватне і публічне право. Розподіл системи права на публічне та приватне $\epsilon$ найбільш дослідженим і широко визнаним в юридичній науці. Малодослідженим залишається питання щодо юридичної відповідальності суб' єктів приватного права.

Приватне право - це упорядкована сукупність юридичних норм, які охороняють і регулюють відносини приватних осіб. Публічне ж право утворюють норми, що закріплюють порядок діяльності органів державної влади та управління. 
Юридична відповідальність в приватному праві має суттєві відмінності, які дозволяють їі виокремити в самостійну юридичну категорію.

Щодо приватної юридичної відповідальності як приватно-правової категорії слід зазначити, що дослідники звернули увагу на дослідження порівняно недавно, розглядаючи особливості юридичної відповідальності суб'єктів публічного та приватного права. Присвячене цій проблемі дослідження занижує оцінку приватно-юридичної відповідальності в порівнянні 3 публічно-правовою. Так, В. С. Чиркин зазначає, що відповідальність юридичної особи публічного права в своїй основі має не приватний, а суспільно-правовий характер. Приватноправова відповідальність, якщо вона $\epsilon$, завжди має менш важливе значення [13, с. 27].

Безумовно, інше значення приватноправова відповідальність набуває в галузях приватного права, де й виявляються найбільш обгрунтовані особливі риси та характер даного виду юридичної відповідальності.

1. За джерелами правового закріплення юридичної відповідальності, приватноправова відповідальність відрізняється від публічно-правової тим, що може передбачатися не лише санкціями норм приватного права, а й бути встановленою також і за волевиявленням самих учасників приватноправових відносин, наприклад, сторонами в індивідуальному договорі.

2. Більшість норм приватного права мають диспозитивний характер. Розглядаючи диспозицію норм права, слід зробити висновок, що 3 норм приватного права диспозитивний характер мають лише ті норми, в диспозиції яких міститься юридична можливість волевиявлення суб'єкта та вплив цього волевиявлення на правову долю правовідносин. Інакше кажучи, правові наслідки ставляться в залежність від поведінки самого учасника правовідносини. Норми-санкції в приватному праві допускають приватне волевиявлення, й застосування до правопорушника юридичної відповідальності здійснюється на розсуд уповноваженого суб'єкта, хоча й в руслі, визначеному публічною владою.

Дане положення грунтується на теорії розмежування приватного і публічного права, яка дотримується формального моменту, тобто того, як розподіляється ініціатива захисту права від порушень. Якщо цей захист порушується на вимогу зацікавленої особи, чиє право було порушено, то ми маємо справу 3 приватним правом. Якщо ж порушення норми викликає ініціативу з боку самої держави (в особі їі органів), нерідко, крім і навіть проти волі потерпілої особи, то перед нами галузь публічного права [14, с. 8]. У публічно-правових відносинах посадова особа, що має повноваження від імені держави залучити правопорушника до юридичної відповідальності, не може відмовитися або ухилитися від таких дій в силу своїх посадових обов'язків.

У той же час не можна не звернути увагу, що державний примус, примусовий характер притаманні будь-якій санкції, яка є заснованим на правовій нормі примусовим заходом. Однак О. С. Йоффе зазначав, що не будь-яка санкція $є$ мірою юридичної відповідальності. Наприклад, майно вилучається з чужого незаконного володіння в примусовому порядку, в наявності санкція є як наслідок правопорушення. Але така санкція буде відповідальністю тому, що не пов'язана 3 будь-яким нестатком для порушника, у якого вилучається річ, що йому не належала [5]. Юридична відповідальність завжди тягне за собою певні позбавлення майнового або особистого характеру.

3. Важливою складовою приватно-юридичної відповідальності, а також її різновидів виступає державний примус. Разом з тим необхідно відзначити, що приватноправова спрямованість цієї відповідальності впливає на характер державного примусу. Тобто останнє не в усіх випадках настання юридичної відповідальності застосовується безпосередньо до суб'єкта приватного права з метою змусити його діяти санкцією певним чином. У приватноправових відносинах можливі випадки, коли правопорушник добровільно відшкодовує заподіяну їм шкоду перед потерпілим, що виключає необхідність вдатися до допомоги компетентних державних органів, що виступає від імені держави таку відповідальність на правопорушника.

Зосереджуючи увагу щодо цивільно-правової відповідальності, в якості недоліку ії визначення слід зазначити, що саме державний примус залишає за межею цивільно-правової відповідальності добровільне відшкодування боржником збитків кредиторові або сплату компенсації, якщо вони зроблені не під загрозою примусу, а через внутрішню переконаність боржника в необхідності відшкодування збитків, сплати цієї компенсації [6].

Слід зазначити, що приватноправова відповідальність, на відміну від цивільно-правової, як правило, але не завжди має майновий характер, оскільки в деяких випадках полягає у скруті особистого характеру (наприклад, відповідальність батьків за злісне ухилення від виконання батьківських обов'язків у сімейному праві). 
4. Однією з істотних рис, що виділяють приватноправову юридичну відповідальність, є така iii риса, за якою один із учасників приватноправових відносин несе відповідальність перед іншим, що випливає з принципу рівноправності, незалежності (автономності) суб’єктів приватного права.

5. Серед особливостей приватно-юридичної відповідальності можна назвати й таку, як відповідність розміру відповідальності наслідків правопорушення (в основному, розміром заподіяної шкоди або збитків). При визначенні меж приватної відповідальності зазвичай виходять з її компенсаційного характеру з метою захистити права потерпілого.

6. У сучасному суспільстві вченими досліджено й надалі досліджуються наступні позиції щодо природи обов'язку, що виникає в межах юридичної відповідальності: позбавлення права, з якого випливає порушений обов'язок; заміна невиконаного обов'язку новим; приєднання до порушеного обов'язку нового. В даному контексті поширеною вбачається позиція в тому аспекті, що реалізація санкцій, не маючи взаємозв'язку із додатковими обов'язками не є юридичною відповідальністю, а лише засобами захисту суб'єктивних прав і забезпечення виконання обов'язків.

Досліджуючи актуальні аспекти примусу до виконання порушених обов'язків заходом відповідальності, автор вважає, що відповідальність передбачає, як покладення додаткових обов'язків, так і державний примус до виконання невиконаних обов'язків. Тобто одне лише $є$ примусовим виконанням невиконаного не визнається відповідальністю $[10 ; 11 ; 12]$.

Висновки. Автор повністю розділяє думку вчених, однак якщо розглядати приватне й публічне право окремо один від одного, то перше насамперед охороняє суб'єктивні права та обов'язки, реалізуючи які суб'єкти задовольняють свої особисті інтереси, а публічне право - суб'єктивні права й обов'язки, реалізація яких стосується інтересів суспільства.. Тому цілісність права не заперечує відмінність, відособленості відображених інтересів, що ним захищаються.

На нашу думку, основними критеріями в даний час спостерігається деяке зближення приватноправових і публічно-правових засад, оскільки держава (окремі ії частини) активно вступають у відносини цивільно-правового характеру, узаконений і широко поширений термін «державні послуги». Проте таке зближення не сприяє їх злиттю. Приватне і публічне право існують об'єктивно, незалежно від визнання чи невизнання такого підрозділу. Разом з тим існує й інша думка, що полягає в тому, що межа між сферами приватного і публічного інтересів суб'єктивна, рухлива і визначається законодавцем. Проте, якщо законодавець буде довільно замінювати приватне право публічним, або навпаки, то це може підірвати суспільний порядок і перешкодити нормальному розвитку держави.

\section{Список використаних джерел}

1. Конституиія України // (Відомості Верховної Ради України (ВВР), 1996, № 30, ст. 141) [Електронний ресурс]. - Режим доступу : https://zakon.rada.gov.ua

2. Басін К. В. Юридична відповідальність: природа, форми реалізації та права людини : автореф дис./ ... канд. юрид. наук : 12.00.01 / НАН України; Інститут держави і права ім. В. М. Корецького. - К., 2006. -19 с.

3. Брагинский М. И., Витрянский В. В. Договорное право: общие положения. - М. : Статут, 1997. - С. 492.

4. Гражданское право : учеб. - Т. 1. - Изд. 4-е, перераб. и доп. / Под ред. А. П. Сергеева, Ю. К. Толстого. - М. : Проспект, 1999. - С. 533.

5. Иоффе О. С. Ответственность по советскому гражданскому праву. - Л. : Изд-во ЛГУ, 1955. - С. 7-8.

6. Кузнєцова Н. Цивільно-правова відповідальність і захист цивільних прав // Про українське право. Часопис кафедри теорії та історії держави і права Київ. нац. ун-ту імені Тараса Шевченка: за ред. проф. І. Безклубого. - 2010. - Число V.

7. Колосова Н. М. Конституционная ответственность в Российской Федерации: ответственность органов государственной власти и иных субъектов права за нарушение конституционного законодательства Российской Федерации. - М. : Городец, 2000. - С. 8.

8. Малеин Н. С. Правонарушение: понятие, причины, ответственность. - М. : Юридическая литература, 1985. C. 134.

9. Оніщенко Н. М. Монізм у праві в контексті сучасного праворозуміння / Н. М. Оніщенко // Держава і право : зб. наукових праць. Юридичні і політичні науки. Випуск 47. - К. : Інститут держави і права ім. В. М. Корецького НАН України, 2010. - С. 3-9.

10. Teremtsova N. The main types understanding to legal liability: the theoretical aspect.// European Perspectives (Politics, Economics, Law). Науково-практичний журнал № 1, 2017. Вид. Спеціалізоване видавництво «ЮНЕСКО СОЦІО». - К. 2017. -180 с. - C.12-18. 
11. Теремцова Н. В. Особливості юридичної відповідальності у контексті правомірної та протиправної поведінки: соціологічний аспект. //Соціологія права. Науково-практичний журнал №№ 1-2(7-8), 2014. Вид. Інститут законодавчих передбачень і правової експертизи. - 2014. - 159 с. - С.111-117. Фахове видання.

12. Теремцова Н. В. Проблема існування позитивної відповідальності в умовах сучасного державотворення в Україні //Малий і середній бізнес. Економіко-правовий науково-практичний журнал «Право, Держава, Економіка». - №№ 1-2 (64-65). -2016. - Вид. навчально-консульт. Центр в Інституті законодавчих передбачень і правової експертизи. - К. 2016. - С. 73-80. - 128c. Фахове видання.

13. Черногор Н. Н. О теоретических проблемах юридической ответственности // Журнал российского права. 2006. - №5. - С. 36.

14. Чиркин В. Е. Юридическое лицо публичного права // Журнал российского права. - 2005. - С. 27.

15. Шериеневич Г. Ф. Понятие о гражданском праве. - Казань : Типография Казанского Императорского Университета, 1898.

\section{Теремцова Н. В. Особливості юридичної відповідальності суб'сктів приватного права}

Проблема юридичної відповідальності в контексті суб'єктів приватного права не в повному обсязі висвітлена на сторінках як вітчизняної, так і зарубіжної юридичної наукової літератури. Проблема юридичної відповідальності, незважаючи на те, що вона обговорюється протягом декількох десятків років, не втратила своєї актуальності і в даний час. В статті автор доводить та дає поняття щодо видів відповідальності та поняття юридичної відповідальності.

Ключові слова: держава, суспільство, юридична відповідальність, обов'язок, реалізація санкцій, суб'єктивне право, примус, приватне право, суспільний порядок.

\section{Teremtsova $\mathrm{N}$. V. the features of legal responsibility of private law subjects}

In the article, the author proves and gives the concept of types of responsibility and the concept of legal responsibility. The problem of legal liability in the context of private law subjects not fully covered in the pages of both domestic and foreign legal scientific literature. The problem of legal liability, even though it is discussed for several decades, has not lost its relevance now.

Key words: state, society, legal responsibility, duty, implementation of sanctions, subjective law, coercion, private law, public order.

DOI: 10.33.66.3/2524-017X-2019-10-271-274

УДК 340.134 : 342

Вікторія Миколаӥвна Тернавська, кандидат юридичних наук, доиент кафедри охорони праичі і навколишнього середовища Київського національного університету будівництва і архітектури

\section{МІСЦЕ І РОЛЬ ПРАВОВОГО МОНІТОРИНГУ ТА ПРАВОВОЇ ЕКСПЕРТИЗИ В СИСТЕМІ ЗАСОБІВ ПРАВОВОЇ ПОЛІТИКИ}

Постановка проблеми. Сучасна правова політика України має низку стратегічних завдань, однак всі вони спрямовані на досягнення загальної мети - модернізації національної правової системи, де правові засоби упорядкування різних сфер життєдіяльності суспільства використовуватимуться задля належного забезпечення законності і правопорядку, умов вільного розвитку особистості та реалізації у повній мірі ії конституційних прав і свобод. В той же час, аналізуючи стан правового життя українського суспільства, можна відзначити низьку ефективність юридичного інструментарію. Причина вбачається у невисокій якості правотворчого процесу, який відбувається без належного аналізу стану соціально-економічних відносин, урахування потреб нового постіндустріального суспільства, змін у суспільній свідомості. Відповідно одним із пріоритетних напрямів правової політики, зокрема конституційно-правової політики, має бути удосконален- 